\title{
Does Education Reduce CO2 Emmisions? Empirical Evidence of The Environmental Kuznets Curve in Indonesia
}

\author{
Rodhiah Umaroh*
}

\section{Faculty of Economics and Bussines, Universitas Gadjah Mada (UGM), Special Region of Yogyakarta, Indonesia}

\begin{abstract}
The purpose of this study is to analyze whether education has a role in energy use in society using the Environmental Kuznets Curve (EKC) hypothesis during the period 1972-2016 in Indonesia. The paper applied the Autoregressive Distrubuted Lag (ARDL) Bound Test approach to identify co-integration relationships among variables in the model. The results confirmed the evidence that education initially increased $\mathrm{CO} 2 \mathrm{emmisions}$ and at some point education reduced $\mathrm{co} 2$ in the short run but not in the long run. In addition, i also found conclusive evidence to support the Inverted U-shaped EKC hypothesis of the relationship between GDP per capita and environmental degradation. The stability test has conducted in estimated model and the result indicated that estimated model is stable over time.
\end{abstract}

Keywords: CO2 Emmision, Environmental Kuznets Curve, Education.

\section{INTRODUCTION}

Study on the relationship between per capita income and environmental degradation has been undertaken by many researchers (Baek \& Choi, 2017; Dinda, 2004; Sehar \& Khan, 2013; Shahbaz, Dube, Ozturk, \& Jalil, 2015) who modeled through the Kuznets Environment Curve hypothesis (EKC) which was first introduced by Grossman \& Krueger (1991) on the study of potential impact of NAFTA. According to the Environmental Kuznets Curve hypothesis in the early stages of economic growth, environmental degradation and pollution are increasing but at certain per capita income levels the trend is reversing. This indicates that the environmental impact indicator is an inverted U-shaped function of per capita income (Stern, 2003). Increased environmental degradation resulting from income inequality and then declines in line with development outcomes.

The environmental indicators in EKC are modeled on the logarithmic quadratic revenue function on environmental hazard emissions although many researchers add new variables in the model specification to improve estimation results such as urbanization and income inequality ( Bond \& Farzin, 2004; Shahbaz et al., 2015). Not only economic indicators are used but human capital indicators are also considered as environmental quality is also determined from the quality of human resources. Education is one of the most widely used human capital indicators despite the issue of endogenity

*Address correspondence to this author at the Faculty of Economics and Bussines, Universitas Gadjah Mada (UGM), Special Region of Yogyakarta, Indonesia; E-mail: dhiah.basuki@gmail.com between education and income (Gangadharan \& Rebecca, 2001). However, the limited number of studies that take account of education cannot find consistent evidence (Balaguer \& Cantavella, 2018). Research conducted by Bond \& Farzin (2004) found out that education has a negative impact on environmental quality. While some studies have found no effect of education on pollution production (Williamson, 2017).

This study focuses on the importance of education on environmental degradation shown by $\mathrm{CO} 2$ emissions. This is based on the assumption that the energy used in the community is determined by the quality of the citizen. As the level of education of citizen increases, it is believed to increase the level of environmental awareness through individual performance and policy makers so that the harmful emissions can be reduced. In addition, a high level of education can create more sophisticated and better technology in production output and emissions (Williamson, 2017). Therefore, based on the Environmental Kuznets Curve hypothesis it is believed that educational enhancement, ceteris paribus, will shift the downward curve due to a decrease in pollution. The purpose of this study is to analyze the role of education on environmental quality in Indonesia in 1972-2016. Other variables used are trade openness, population and industrial value added. The research method used is Autoregressive Distributed Lag (ARDL) Bound Testing which can estimate short and long term relationship in estimated model. This research is structured as follows: in section 2 encompassing the literature review, section 3 is a research methodology and in sections 4 and 5 includes results and conclusions.

๑) 2019 Lifescience Global 


\section{LITERATURE REVIEW}

The term Environmental Kuznets Curve is named for Simon Kuznets (1955) hypothesizing that the inequality of income initially rises and then falls as economic growth increases. The EKC concept was first introduced by Grossman and Krueger (1991) on a groundbreaking study of the potential impact of the North American free trade agreement (NAFTA). Based on previous research, the EKC reversed U-shaped curve is due to the fact that in the first time the country began to develop, they also started industrialization which produced a lot of production output and this will result in a large emission pollution but later with increasing prosperity there is a change in the economic structure of the country that started the practice cleaner and more service-oriented industries. Critics of conventional EKC concepts emerge from some who argue that EKC is nothing more than a dynamic process. They claim that the EKC curve will continue to rise and become a horizontal line at the maximum pollution levels that can be generated as globalization will drive the industry. Another conflicting argument is that although the amount of pollution can be lowered by increasing revenue, the industry will continue to produce new pollution, especially in unregulated potential pollutants (Dasgupta, Laplante, Wang, \& Wheeler, 2002).

In addition, there are many studies that cannot proved reversed U-shaped curve hypothesis but found a positive relationship between income and environmental degradation (Chuanqi \& Xiaojun, 2013; Costantini, Martini, Lavoro, Eni, \& Mattei, 2006; Mahmood, Shahab, \& Sadaf, 2014; Pravesh, 2013). Moreover, Stern (2004) argues that if there is a relationship as expressed in the concept of EKC, it is more due to the effects of trade on the distribution of industrial pollution. According to the Heckser-Ohlin trade theory, it shows that if they are in a free trade area, developing countries will specialize in the production of goods and services so that they only use the inputs that most needed in the specialty segment so that production becomes more efficient and the pollution is reduced. But there also optimistic with EKC hypothesis as many researchers who confirm the existence of inverted U-shape curve (Balaguer \& Cantavella, 2018; Behboudi, 2014; Mugableh, 2013).

Dasgupta et al. (2002) used a general theory model to explain if producers pay the social marginal cost of pollution then the relationship between emissions and income will depend on the preferences and technologies used. If the preference is homotetic then the percentage increase in income will lead an increase in the percentage of consumption at the same level but if the preference is non-homotetic then there is a difference between the increase in income and consumption. In addition, some researchers argue that EKC is not only affected by economic factors and structures alone but they also use other factors such as human capital, political stability, technology and corruption since the behavior of the population also plays an important role in the environment (Behboudi, 2014; Dinda, 2004; Sahli \& Rejeb, 2015; Sugiawan \& Managi, 2016; Williamson, 2017).

Several studies have been conducted on the study of the relationship between education and carbon dioxide emissions (CO2) (Balaguer \& Cantavella, 2018; Bond \& Farzin, 2004; Williamson, 2017). There are three reasons why education probably have a positive impact on environmental quality (Bond \& Farzin, 2004). First, educated people are assumed to have higher levels of environmental awareness so that they will behave consistently on environmental protection. According to Mirza Md dan Moyen Uddin (2014) the formal education system provides a framework that is ready to reach most of the population and can help future generations aware of the importance of environmental preservation. Second, educated people are more capable to voice their aspiration to the environment using existing channels with groups or organizations that they are more vocal on environmental issues and policy that support environmental conservation. Third, the higher educated population is more likely to produce progressive community services in the environment and create more democratic policies and more accepting of public demand for environmental quality.

A positive relationship between education and environmental quality has also been a concern for many researchers. Most of them estimate the relationship in the single direction, but Balaguer \& Cantavella (2018) consider possibility the two opposite results in estimation. they state that education at first probably increase pollution because it takes a lot of energy resources but after reaching a certain point increased education will actually reduce pollution. This concept is similar to the relationship between income and environmental quality in the EKC hypothesis. The expansion of educational potential should not be ignored by governments to reduce environmental degradation. Improving the quality and quantity of education in every country is of great concern to create 
an advanced society both in economic and social terms and environmental awareness.

\section{METHODOLOGY}

\subsection{Data}

The modeling of the hypothesis of Environmental Kuznets Curve in this study used period of time series data of 1972-2016 in Indonesia. Variable used is CO2 emission in metric tons per capita as dependent variable while independent variable is GDP per capita as proxy of income per capita. To estimate education, some researchers use government spending on education as a proxy on education (Ekperiware, Olatayo, \& Egbetokun, 2017; Mirza Md. Moyen Uddin, 2014), years of schooling (Williamson, 2017) and literacy rate (Bond \& Farzin, 2004). However, this study uses data as used in the previous paper by Balaguer \& Cantavella (2018), namely tertiary school enrollment expressed as a percentage. Other variables are added in the estimation model because it is believed to have an effect on $\mathrm{CO} 2$ emissions such as trade openess, population and industrial value added. All data taken from the World Bank Development Indicator (WDI) and data not in percent form will be transformed into logarithms.

\subsection{Model Specifications}

The estimation model used in this study is a modified EKC hypothesis model by Balaguer \& Cantavella (2018) where CO2 emissions are affected by income per capita (GDP), Education (Ed), Trade Openess (Tr), number of population (Pop) and Indsutry Value Added (Ind).

$$
C \mathrm{O}_{2}=f\left(G D P, G D P^{2}, E d, E D^{2}, T r, P o p, \text { Ind }\right)
$$

The linear model specification equation is converted into a log-linear specification. This is done because the log-linear specification is more feasible and efficient than a simple linear model. Moreover, logarithmically transforming variables in regression model is very common way to handle situation where a non-linier relationship exist between the independent and dependent variables (Kenneth, 2011). Furthermore, the logarithmic form of the variable provides an direct interpretation of the estimate of elasticity. Therefore, the estimation model specification becomes:

$$
\begin{aligned}
C O_{2 t}= & \alpha_{0}+\alpha_{1} \operatorname{Ln}(G D P)_{t}+\alpha_{2} \operatorname{Ln}\left(G D P^{2}\right)_{t}+\alpha_{3} E d_{t} \\
& +\alpha_{4} E D^{2}{ }_{t}+\alpha_{5} T_{t}+\alpha_{7} \operatorname{Ln}(P o p)+\alpha_{8} I_{t}+\varepsilon_{t}
\end{aligned}
$$

Where $\varepsilon$ is an error term or residual. The EKC model hypothesizes that $\alpha_{G D P}>0$ and $\alpha_{G D P^{2}}<0$ in order to form an inverted U-shaped curve. While I hypothesize the coefficients koefisien $\alpha_{E d}>0$ and $\alpha_{E d^{2}}<0$ as the assumption that initially education will increase $\mathrm{CO} 2$ emissions as it requires a lot of energy and then compensated by decreasing pollution as higher education in society. Coefficient $\alpha_{T r}>0$ or expected positive sign because the higher level of trade openness will increase the production that will eventually increase the number of harmful emissions. However, theoretically impact of trade liberalization is not clear. Relatively lenient environmental regulations suggest that the use of environment is relatively cheap to the firm. In the standard Heckscher-Ohlin (HO) trade model, a country with such a relatively low factor price ratio (or relatively large physical stock of a factor) would be classified as relatively environmentt abundant. Free trade can actually facilitate technology transfer in every country so that the higher level of trade openness will actually make industrial production more efficient with more sophisticated technology and cleaner pollution (Dean, 2018). Increasing population associated with increasing energy use to meet the increasing energy consumption, therefore I excpet coefficient $\alpha_{\text {Pop }}>0$ or positive sign. Lastly, for $\alpha_{-}$Ind < 0 is expected to be a negative sign because $\mathrm{CO} 2$ emissions are closely related to contributions from industry sectors in a country.

\subsubsection{Unit Root Test}

Empirical studies on time series data assume that the data is stationary (Ericsson \& Mackinnon, 1999). Nelson \& Plosser (1982) is the first who show that nonstationary data will have a significant impact on the economy. Therefore, before estimating the time series macroeconomic model, it is necessary to identify the nature of time series data. Stasionarity test is important to see if there are unit roots in time series data so that the error of model specification and bias or spurious regression can be avoided. Augmented Dicky Fuller (ADF) test is used as a test for detection of stationarity in this study. According to Richardson \& Andersen (1995) the ADF test is performed by adding lag or first difference to the dependent variable to eliminate the autocorrelation or by including error correction term. Assuming a random walk with drift model around the stochastic trend is determined by increasing the number of lags on the variable. The ADF test procedure is applied in the following model:

$$
\Delta y_{t}=\alpha+\beta_{t}+\gamma y_{t-1}+\ldots+\delta_{\rho-1} \Delta y_{t-\rho+1}+\varepsilon_{t}
$$

The null hypothesis (data requires a differenced process to be stationary) and the alternative hypothesis 
is (stationary data and not necessarily differenced). Criteria for decision making is to compare the value of ADF statistics with the critical value of Mackinnon to reject the hypothesis of the root unit. If the ADF statistic value is smaller than the critical value of Mackinnon then Ho (non stationary data) is rejected and vice versa.

\subsubsection{Estimation Model}

This study used the Bound testing Autostegressive Distributed Lag (ARDL) approach developed by Pesaran \& Shin (1997) to identify short and long run relationships between $\mathrm{CO} 2$ emissions, GDP per capita, education, trade openess, population and indutrial value added. The use of the bound test technique has three approval. First, Pesaran, Shin, \& Smith (2001) support the use of the ARDL model to estimate the level of relationships among variables because the ARDL model states when an order of ARDL has been determined then to see the relationship between variables can be done with OLS estimation. Second, the bound test allows for the combination of independent variables integrated in first order I (1) and order 0 । (0). Thus, any independent variable in the equation can have different order integration levels. Third, the bound test technique can be used for small and large sample sizes (Pesaran et al., 2001). In addition, according to Laurenceson \& Chai (2003) the benefit of the ARDL bound test is the unrestricted ECM model that appears to obtain optimal lag on generating data (d.g.p) in general-to-specific (Ahmed, Dey, \& Das, 2015).

In the usual cointegration method it may have problems with endogenity whereas the ARDL method can distinguish which is the dependent variable and the explanatory variable. Moreover, the estimation results obtained from the ARDL method for analyzing cointegration (bound test) is efficient and unbiased because ARDL eliminates the possibility of serial correlation and endogenity. The ARDL procedure allows estimation on variables with different lag numbers while Johanson can not (Ahmed et al., 2015). Finally, Pesaran \& Shin (1997) stated that an appropriate modification of ARDL model order is able to eliminate residual correlation serial problem and endogenous variable problem.

The bound test procedure for cointegration is developed within the framework of autoregressive distributed lag and can be done using two stages. In the first stage, testing the long-term relationship between variables based on theory. In the second stage, testing of short-run relationships between variables. Without knowing information about long-run relationships between variables, the unrestricted error correction (UEC) regression can be estimated as follows:

$$
\begin{aligned}
& \Delta(C O 2)=\beta_{0}+\beta_{1} \ln (G D P)_{t-1}+\beta_{2} \ln \left(G D P^{2}\right)_{t-1}+\beta_{3}(E d)_{t-1} \\
& +\beta_{4}\left(E d^{2}\right)_{t-1}+\beta_{5}(T r)_{t-1}+\beta_{6}(\text { LnPop })_{t-1}+\beta_{7}(\text { Ind })_{t-1} \\
& +\sum_{i=1}^{l} \beta_{8} \Delta(C O 2)_{t-1}+\sum_{i=0}^{m} \beta_{9} \Delta(\ln G D P)_{t-1}+\sum_{i=0}^{n} \beta_{10} \Delta\left(\ln G D P^{2}\right)_{t-1} \\
& +\sum_{i=0}^{o} \beta_{11} \Delta(E d)_{t-1}+\sum_{i=0}^{p} \beta_{12} \Delta\left(E d^{2}\right)_{t-1}+\sum_{i=0}^{q} \beta_{13} \Delta(T r)_{t-1} \\
& +\sum_{i=0}^{r} \beta_{14} \Delta(\text { LnPop })_{t-1}+\sum_{i=0}^{s} \beta_{15} \Delta(\text { Ind })_{t-1}+\varepsilon_{t}
\end{aligned}
$$

The ARDL Bound testing approach used to determine cointegration depends on the critical value tabulated by Pesaran et al. (2001) to establish cointegration decisions of all variables. The null hypothesis no cointegration within the model is $H_{0}=\beta_{1}=\beta_{2}=\beta_{3}=\beta_{4}=\beta_{5}=\beta_{6}=\beta_{7}=0 . \quad$ Alternative hypothesis that there is cointegration in the model is $H_{0}=\beta_{1} \neq \beta_{2} \neq \beta_{3} \neq \beta_{4} \neq \beta_{5} \neq \beta_{6} \neq \beta_{7} \neq 0$. If the statistical test goes beyond the upper critical value, the null hypothesis no cointegration can be rejected regardless whether the variable has a 1 or 0 order integration. If the statistical test falls below the lower critical value, the null hypothesis can not be rejected. However, if the statistical test is between two bound values, then the result can not be determined. In addition, if the order of integration of each variable is known and all variables are integrated in the first order I (1), then the decision should be based on the upper bound value. Whereas, if all variables are integrated on the order of 0 I (0) then the decision making is based on the lower bound value.

In the second stage, if there is a long-run relationship then the augmented ARDL model $(m, n, o$, $p, q, r, s$ ) will be estimated using the following equation:

$$
\begin{aligned}
& \Delta(C O 2)=\beta_{0}+\sum_{1=0}^{m} \beta_{9} \Delta(\ln G D P)_{t-1}+\sum_{1=0}^{n} \beta_{10} \Delta\left(\operatorname{LnGDP} P^{2}\right)_{t-1} \\
& +\sum_{1=0}^{o} \beta_{11} \Delta(E d)_{t-1}+\sum_{1=0}^{p} \beta_{12} \Delta\left(E d^{2}\right)_{t-1}+\sum_{1=0}^{q} \beta_{13} \Delta(T r)_{t-1} \\
& +\sum_{1=0}^{r} \beta_{14} \Delta(\text { LnPop })_{t-1}+\sum_{1=0}^{s} \beta_{15} \Delta(\text { Ind })_{t-1}+\theta E C T_{t}+\varepsilon_{t}
\end{aligned}
$$

Where $\beta_{9}, \beta_{10}, \beta_{11}, \beta_{12}, \beta_{13}, \beta_{14}, \beta_{15}$ the short-run dynamic coefficient on the model, $\theta$ is the error correction term or speed of convergence adjustment to equilibrium. sign $\theta$ should be negative and significant to ensure dynamics to long-run equilibrium, the value is usually around -1 and 0 . The value of -1 indicates a 
perfect convergence whereas 0 means there is no convergence (Ahmed et al. 2015). The goodness of fit for the ARDL model is checked through the cumulative sume of recursive residual (CUSUM) stability test and cumulative sum squares of recursuve residuals (CUSUMSQ). Furthermore, for diagnostic tests (Breusch Godfrey Serial Correlation LM Test and Heterokedasticity test) will be used to test the correlation and heterocedastisity series present in the model.

\section{RESULTS AND FINDINGS}

In contrast to other cointegration test procedures, the cointegration bound test ARDL test does not require all the integrated variables at the same order. In the cointegration test ARDL bound testing is developed on the basis of the variables integrated in order I (0) or I (1), or when all the variables are integrated in order I (1). Ouattara (2004) stated that if there are variables integrated in order 2 then the F-statistic for cointegration becomes inconclusive. Therefore I use unit root test ADF to check the variable stationarity in the model. Table 1 exhibited that all variables are integrated in order of 1 or the first difference, which means the data has been qualified to use the ARDL bound testing approach and can be used as an appropriate tool for analyzing long-run relationships.
The next procedure in ARDL Bound testing by Pesaran, Shin, \& Smith (2001) is the need for an adequate lag length in variables to remove any serial correlation. Optimal lag selection is based on Akaike Information Criterion (AIC) criteria. The appropriate selection of lag order is necessary for unbiased and reliable result. Table 2 showed the maximum lag length selected in the estimation model and the F-statistic value is above the critical lower bound and upper bound on the $5 \%$ significance which confirm that there is cointegration between the variables when $\mathrm{CO} 2$ is the dependent variable. The issue of autocorrelation and heteroscedasticity is also not proven from the results of Breusch Godfey LM test and ARCH LM test. Model specification is well constructed.

Furthermore, the stability test is used to investigate the stability of parameters in the long run and short run. In doing so, the cumulative sum (CUSUM) and cumulative sum squares (CUSUMSQ) tests have been applied. Pesaran et al. (2001) stated that CUSUM and CUSUMQ are required to test the stability coefficients in the model. Stability test results show stable parameters over time.

After a long-run cointegration relationship with Fstatistics is discovered, further estimation of the short-

Table 1: Unit Root Test

\begin{tabular}{|c|c|c|c|c|}
\hline Variable & \multicolumn{2}{|c|}{ ADF test Statistic } & \multicolumn{2}{|c|}{ PP test statistic } \\
\hline $\mathrm{CO} 2$ & -0.695816 & $-0.3462501^{*}$ & -0.284678 & $-3.542362^{\star *}$ \\
\hline $\operatorname{Ln}(G D P)$ & 2.509856 & 0.044210 & 2.509856 & -0.275838 \\
\hline $\operatorname{Ln}(G D P)^{2}$ & 5.693830 & 2.195775 & 5.693830 & 2.195775 \\
\hline $\operatorname{Tr}$ & $-3.533943^{* *}$ & $-3.360313^{* *}$ & $-3.525680^{* *}$ & $-3.365236^{\star *}$ \\
\hline $\operatorname{Ln}(P o p)$ & $-3.931443^{* * *}$ & 1.321824 & -2.516603 & -1.711335 \\
\hline Ind & 2.672537 & -0.600624 & 2.522455 & -0.795080 \\
\hline$\triangle \mathrm{CO} 2$ & $-6.932611^{* * *}$ & $-6.848757^{* * *}$ & $-10.03834^{* * *}$ & $-10.35739^{* * *}$ \\
\hline$\Delta E d$ & $-5.988915^{\star * *}$ & $-5.231641^{* * *}$ & $-5.960644^{* * *}-$ & $-5.972705^{\star * *}$ \\
\hline$\Delta E d^{2}$ & 0.313018 & $-6.258122^{* \star *}$ & $-5.742367^{\star \star *}$ & $-6.021322^{\star \star *}$ \\
\hline$\Delta T r$ & $-9.861697^{\star * *}$ & $-9.985356^{* \star *}$ & $-10.09135^{\star \star *}$ & $-10.95210^{\star \star *}$ \\
\hline$\Delta L n(P o p)$ & 0.534289 & $-3.607130^{* *}$ & -1.053837 & -1.870872 \\
\hline$\Delta / n d$ & $-4.516506^{\star * *}$ & $-5.129120^{* * *}$ & $-4.516506^{\star * *}$ & $-5.006889^{* * *}$ \\
\hline
\end{tabular}

Note: $1 .{ }^{* * *},{ }^{* *}$ and ${ }^{*}$ are $1 \%, 5 \%$ and $10 \%$ of significant levels, respectively. 2. The lag length has been choosen base on the AIC for ADF test. 
Table 2: Model Selection and Cointegration Results

\begin{tabular}{|c|c|c|c|c|c|c|c|c|}
\hline Explanatory variables & $\mathrm{CO}_{t}$ & $\operatorname{LnGDP}_{t}$ & $\operatorname{LnGDP}_{t}{ }_{t}$ & $\mathrm{Ed}_{\mathrm{t}}$ & $E d^{2}{ }_{t}$ & $T r_{t}$ & $\operatorname{LnPop}_{t}$ & Ind $_{t}$ \\
\hline F-statistics & 10.448 & & & & & & & \\
\hline \multicolumn{9}{|l|}{ Critical values $(5 \%)$} \\
\hline Upper bound & 2.69 & & & & & & & \\
\hline Breusch-Godfrey LM test [2] & 0.0668 & & & & & & & \\
\hline ARCH LM test [2] & 0.4349 & & & & & & & \\
\hline
\end{tabular}
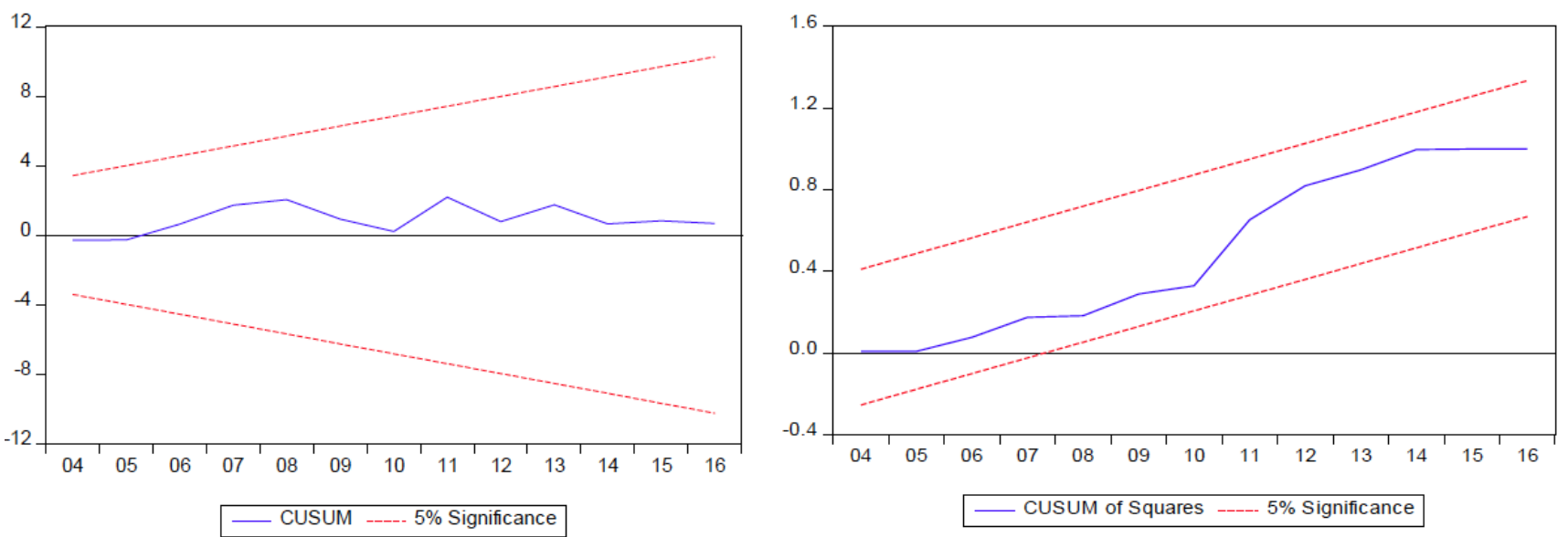

Figure 1: Plot of CUSUM and CUSUMSQ.

term correction error is required (Table 3 ). The ECM variable in the model is a long-run dynamic residual lagged period estimation with negative and significant coefficients at the $1 \%$ level, ensuring that long-run equilibrium convergence can be achieved. The value of the ECM coefficient means that about 84 percent of the deviation from the long-run equilibrium is adjusted every year and the remaining 12 percent in the next year. It also shows that once disequilibrium occurs it will take more than a year to adjust to equilibrium.

Short and long run estimates are presented in Tables 3 and $\mathbf{4}$, respectively. This finding is very interesting to discuss because in the short term the GDP coefficient is negative and the quadratic GDP is positive indicating that the EKC hypothesis can not be confirmed. These results are similarly found in previous studies (Appiah, Du, Musah, \& Afriyie, 2017; Mahmood et al., 2014). In the long run, however, the reverse Ushaped hypothesis reveals that the GDP and GDP squares coefficients are positive and negative which means that initially an increase in GDP per capita will increase $\mathrm{CO} 2$ emissions but at a certain point a rise in
GDP per capita will reduce $\mathrm{CO} 2$ emissions. This difference in results is also confirmed by (Baiardi, 2014; Balaguer \& Cantavella, 2018; Gangadharan \& Rebecca, 2001; Mugableh, 2013; Sahli \& Rejeb, 2015; Shahbaz et al., 2015). Indonesia as a developing country is currently facing a massive industrialization to catch up with other countries, perhaps this explains why the findings of EKC hypothesis proved in the long run but not in the short run because at this time Indonesia has not reached the turning point.

The education and quadratic education coefficients proxied with higher education are significantly different from zero with positive and negative signs in the short run. This suggests that the higher the education level will shift the decreased EKC curve. Theoretically, the high level of education in society will raise awareness of the negative externalities of the environment and seek to reduce those externalities (Williamson, 2017). In addition, as education increases are believed to be followed by increased use of more environmentally friendly and efficient technologies that will reduce emissions (Dinda, 2004). Similar results are also 
Table 3: Short Run Estimates

\begin{tabular}{|c|c|c|c|}
\hline \multicolumn{4}{|c|}{ Dependent variable $=\mathrm{CO}_{t}$} \\
\hline Variable & Coefficient & Standard error & t-statistic \\
\hline$\Delta L n G D P_{t}$ & -0.005941 & 0.001066 & $-5.572992^{* * *}$ \\
\hline$\Delta L n G D P_{t}^{2}$ & 0.000821 & 0.000202 & $4.074425^{\star \star \star}$ \\
\hline$\Delta E d_{t}$ & 0.115481 & 0.025669 & $4.498830^{* * *}$ \\
\hline$\Delta E d^{2}{ }_{t}$ & -0.001740 & 0.000531 & $-3.278660^{* * *}$ \\
\hline$\Delta T r_{t}$ & -0.015891 & 0.001936 & $-8.207227^{* * *}$ \\
\hline$\Delta L n P o p_{t}$ & 0.000643 & 0.000478 & $6.208664^{* * *}$ \\
\hline$\Delta / n d_{t}$ & 0.000133 & 0.000477 & $2.800298^{* * *}$ \\
\hline$E C M_{t-1}$ & -0.840210 & 0.074092 & $-11.34008^{\star * *}$ \\
\hline \multicolumn{4}{|l|}{ Statistics } \\
\hline R-squared & 0.96 & & \\
\hline S.E of regression & 0.0411 & & \\
\hline AIC & -3.2353 & & \\
\hline F-statistic & 23.3075 & & \\
\hline
\end{tabular}

${ }^{*},{ }^{* *},{ }^{* * *}$ are $1 \%, 5 \%$ and $10 \%$ significant levels.

supported by previous research (Balaguer \& Cantavella, 2018; Costantini et al., 2006; Mirza Md. Moyen Uddin, 2014). However, in the long run the educational coefficients show significantly no different from zero contrary to the initial notion. The reason for this outcome is still unknown and requires further research.

Other interesting results are found in trade openness. Dean (2018) states that the existence of free trade has multiple effects on $\mathrm{CO} 2$ emissions. On the one hand, trade openness is believed to have a positive impact on increasing pollution as more countries trade between countries, the greater their production and make the $\mathrm{CO} 2$ emissions increase. But on the other hand, it is also believed to have a negative impact on the production of $\mathrm{CO} 2$ emissions due to the product specialization process. The results in this study show negative and significant trade openness coefficients on $\mathrm{CO} 2$ emissions in both the short and long term as well as the previous findings (Dean, 2018). This fact gives an optimistic outcome on the trade in favor of the environment.

Furthermore, the coefficient of number of population variable shows significant positive and negative coefficients in the short and long run, respectively. Along with population growth, the need for energy increases so assuming $\mathrm{CO} 2$ emissions increase. But this increase is quite small because in the short run every increase in population by 1 percent will increase CO2 emissions by 0.0006 percent. This results are similar to other studies (Fu, Wang, \& Zhang, 2014; Sehar \& Khan, 2013). In the long run, in contrast, the

Table 4: Long Run Estimates

\begin{tabular}{|c|c|c|c|}
\hline \multicolumn{4}{|c|}{ Dependent variable $=\mathrm{CO}_{t}$} \\
\hline Variable & Coefficient & Standard error & t-statistic \\
\hline $\operatorname{LnGDP_{t}}$ & 0.008585 & 0.003221 & $2.665261^{* *}$ \\
\hline $\operatorname{LnGDP}_{t}{ }_{t}$ & -0.000748 & 0.000376 & $-1.991004^{* *}$ \\
\hline$E d_{t}$ & -0.043683 & 0.073172 & -0.596989 \\
\hline$E d_{t}^{2}$ & 0.002387 & 0.001846 & 1.293432 \\
\hline$T r_{t}$ & -0.036319 & 0.015969 & $-2.274408^{* *}$ \\
\hline $\operatorname{LnPop}_{t}$ & -0.000451 & 0.000177 & $-2.552703^{* *}$ \\
\hline $\operatorname{lnd}_{t}$ & -0.000594 & 0.000258 & $-2.300570^{\star *}$ \\
\hline
\end{tabular}

${ }^{*},{ }^{* *},{ }^{* * *}$ are $1 \%, 5 \%$ and $10 \%$ significant levels. 
number of populations has negative sign and unambiguesly significant (Franklin \& Ruth, 2012). However, in the long term, energy demand is likely to decrease due to the constant supply of energy.

Finally, industry contributions to GDP also have a different impact on $\mathrm{CO} 2$ emissions. In the short term the coefficient is positive and significant as previously assumed. CO2 emissions have increased over the years since the industrialization and the speed of economic activity. Increased industrial activity also contributes greatly to pollution contributions, especially for industries that use fossil fuels. Indonesia is a developing country that has considerable industrial activity so that the results are not surprising, some researchers have also confirmed these findings (Alam, 2014, 2015; Appiah et al., 2017). However, in the long run the industry value added to GDP has a negative relationship with $\mathrm{CO} 2$ emissions. In connection with this result beside due to the use of more sophisticated industrial technology in the future so that more efficient pollution production is also caused by the added value of industry in GDP may decrease over time because economic activity is more focused on the service sector in the future.

\section{CONCLUSION}

This study aims to identify whether education has a role to environmental degradation estimated with carbon dioxide (CO2) emissions in Indonesia during the period 1976-2016. Borrowing the Environmental Kuznets Curve hypothesis model developed by Grossman \& Krueger (1991) with the Autoregressive Distributed Lag approach to estimate linear and nonlinear relationships between education and environmental quality. This idea begins that the extent to which pollution is generated will depend on the educational level of the community and have an two opposite effect. The first time a society first gets an education will increase energy demand as one of the inputs from education itself so that carbon dioxide emissions will increase. But then, education will make people smarter both of cognitive and behavioral where they will be more aware of the importance of environmental quality so that they will tend to create and use technology more efficiently in the production of emissions. Ultimately environmental quality can be improved over the long run.

This study also includes other variables such as economic growth in accordance with the EKC hypothesis, trade, population and industrial activity.
The results show that education contributes to the reduction of carbon dioxide emissions in the short run but not in the long run. Certainly, this results require further research because according to previous research find out the investment result of human capital like education and health in long run also improve the quality of environment. Nevertheless, these findings can also be used as a reference for the Indonesian government to improve the quality of education, especially in higher education as a solution of sustainable economic and environmental development. Higher education is also one of the optimal agents of change for environmental empowerment along with population growth. Supposedly with a qualified educational level although population growth continues to increase but the quality of the environment can be maintained because educated people will be able to manage the environment and energy resources well. These results have been controlled by other variables such as trade opennes, number of population and industrial activity that indicate the optimism for improving the quality of the environment in the future.

This study also reveals interesting results on the shape of the $U$ curve in the EKC hypothesis. In the short run, instead of inverted U-shaped this study suggest normal U-shaped on the relationship of economic growth and $\mathrm{CO} 2$ emissions. This indicates that Indonesia still has a big task to be able to improve the quality of the environment in line with the growing economic growth is significant. While in the long run, the results confirm a turning point on the U-shaped inverted curve. There are several things to be concern from this result, the existence of quadratic variables of education that probably make the coefficient of income bias. Therefore, policy makers are advised to be cautious when determining the turning point of the EKC curve in this study.

Finally, for the next researchers it may be possible to use other variables as proxies of better education according to the conditions of the country under study and use larger data. The hope of this study could motivate other researchers to consider education as a determinant of $\mathrm{CO} 2$ emissions or other environmental indicators.

\section{ACKNOWLEDGEMENT}

Indonesia Endowment Fund for Education (LPDP) Indonesia is gratefully akcnowledged. I am thankful to those who provided aspiring guidance and invaluably constructive criticism. 


\section{REFERENCES}

Ahmed, M. U., Dey, M., \& Das, D. L. (2015). Evidence on the Relationship between Price Level and Macroeconomic Policies : Perspective of Bangladesh. Journal of International and Global Economic Studies, 8(2), 49-90.

Alam, J. (2014). On the Relationship between Economic Growth and CO2 Emissions: The Bangladesh Experience Janifar. IOSR Journal of Economics and Finance, 5(6), 36-41. https://doi.org/10.9790/5933-05613641

Alam, J. (2015). Impact of Agriculture , Industry and Service Sector' $s$ Value Added in the GDP on CO2 Emissions of Selected South Asian Countries. World Review of Business Research, 5(2), 39-59.

Appiah, K., Du, J., Musah, A. I., \& Afriyie, S. (2017). Investigation of the Relationship between Economic Growth and Carbon Dioxide ( CO 2 ) Emissions as Economic Structure Changes : Evidence from Ghana. Resources and Environment, 7(6), 160-167. https://doi.org/10.5923/j.re.20170706.02

Baek, J., \& Choi, Y. (2017). Does Foreign Direct Investment Harm the Environment in Developing Countries? Dynamic Panel Analysis of Latin American Countries. Economies, 5(4), 39. https://doi.org/10.3390/economies5040039

Baiardi, D. (2014). Technological Progress and the Environmental Kuznets Curve in the Twenty Regions of Italy. J. Econ. Anal. Policy, 14(4), 1501-1542.

https://doi.org/10.1515/bejeap-2013-0120

Balaguer, J., \& Cantavella, M. (2018). The role of education in the Environmental Kuznets Curve. Evidence from Australian data. Energy Economics, 70, 289-296. https://doi.org/10.1016/j.eneco.2018.01.021

Behboudi, D. (2014). Sustainable Development, Human Development and Institutional Quality ( Case of Middle East Countries ), 6(2), 1-12.

Bond, C. A., \& Farzin, H. (2004). Freedom from Pollution? The State, the People, and the Environmental Kuznets Curve. Working Papers 190904, University of California, Davis, Department of Agricultural and Resource Economics. https://doi.org/10.2139/ssrn.502923

Chuanqi, F., \& Xiaojun, Z. (2013). An Empirical Study of the Environmental Kuznets Curve in Sichuan Province, China. Environment and Pollution, 2(3), 107-115. https://doi.org/10.5539/ep.v2n3p107

Costantini, V., Martini, C., Lavoro, N. D. I., Eni, F., \& Mattei, E. (2006). A Modified Environmental Kuznets Curve for Sustainable Development Assessment Using Panel Data The opinions expressed in this paper do not necessarily reflect the position of, (I). https://doi.org/10.2139/ssrn.951457

Dasgupta, S., Laplante, B., Wang, H., \& Wheeler, D. (2002). Confronting the Environmental Kuznets Curve. Journal of Economic Perspectives, 16(1), 147-168. https://doi.org/10.1257/0895330027157

Dean, J. M. (2018). Does Trade Liberalization Harm the Environment? A New Test. The Canadian Journal of Economics, 35(4), 819-842. R https://doi.org/10.1111/0008-4085.00155

Dinda, S. (2004). Environmental Kuznets Curve: An Envelope of Technological Progress. MPRA Paper No. 28092.

Ekperiware, M. C., Olatayo, T. O., \& Egbetokun, A. A. (2017). Human capital and sustainable development in Nigeria: How can economic growth suffice environmental degradation? Economics Discussion Papers, No 2017-29, 1-25.

Ericsson, N. R., \& Mackinnon, J. G. (1999). Distributions of Error Correction Tests for Cointgration. International Flnance Discussion Papers, No. 655, 1-48.
Franklin, R. S., \& Ruth, M. (2012). Growing Up and Cleaning Up: The Environmental Kuznets Curve Redux. Applied Geography, 32(1), 29-39. https://doi.org/10.1016/j.apgeog.2010.10.014

Fu, Y. B., Wang, S. X., \& Zhang, Z. G. (2014). Population growth and the Environmental Kuznets Curve. Simon Fraser University.

Gangadharan, L., \& Rebecca, M. (2001). Interrelationships between income, health and the environment: extending the Environmental Kuznets Curve hypothesis, 36, 513-531. https://doi.org/10.1016/S0921-8009(00)00250-0

Grossman, G. M., \& Krueger, A. B. (1991). Environmental Impacts of a North American Free Trade Agreement. National Bureau of Economic Research Working Paper Series, No. 3914, 1-57. https://doi.org/10.3386/w3914

Kenneth, B. (2011). Linear Regression Models with Logarithmic Transformations. Methodology Institute, London School of Economics, 1-8. Retrieved from http://www.kenbenoit.net/courses/ME104/logmodels2.pdf

Kuznets, S. (1955). Economic Growth and Income Inequality. American Economic Association, 45(1), 1-28. Retrieved from http://www.jstor.org/stable/1811581

Laurenceson, J., \& Chai, J. C. . (2003). Financial Reform and Economic Development in China. Advances in Chinese Economic Studies Series. https://doi.org/10.4337/9781843767190

Mahmood, M. T., Shahab, \& Sadaf. (2014). Energy, Emissions and the Economy: Empirical Analysis from Pakistan. The Pakistan Development Review, 53(4), 383-401. https://doi.org/10.30541/v53i4llpp.383-401

Mirza Md. Moyen Uddin. (2014). Causal Relationship between Education, Carbon Dioxide (CO2)Emission and Economic Growth in Bangladeshln. IOSR Journal Of Humanities And Social Science (IOSR-JHSS), 19(4), 60-67. Retrieved from http://www.iosrjournals.org/iosr-jhss/papers/Vol19issue4/Version-8/L019486067.pdf

Mugableh, M. I. (2013). Analysing the CO2 Emissions Function in Malaysia: Autoregressive Distributed Lag Approach. Procedia Economics and Finance, 5(13), 571-580. https://doi.org/10.1016/S2212-5671(13)00067-1

Nelson, C. R., \& Plosser, C. I. (1982). Trends and random walks in macroeconomic time series: some evidence and implications. Journal of Monetary Economu, 10(1), 39-62. https://doi.org/10.1016/0304-3932(82)90012-5

Pesaran, H., \& Shin, Y. (1997). An autoregressive distributed lag modelling approach to cointegration analysis. Econometrics and Economic Theory in the 20th Century: The Ragnar Frisch Centennial Symposium., 1-31. https://doi.org/10.1017/CCOL521633230

Pesaran, H., Shin, Y., \& Smith, R. J. (2001). Bounds testing approaches to the analysis of level relationships. Journal of Applied Econometrics, 16(3), 289-326. https://doi.org/10.1002/jae.616

Pravesh, T. (2013). Reexamining the Environmental Kuznets Curve: Evidence from Time Series. Financial and Quantitative Analysis, 2(30), 30-42.

Richardson, G. P., \& Andersen, D. F. (1995). Teamwork in group model building. System Dynamics Review, 11(2), 113-137. https://doi.org/10.1002/sdr.4260110203

Sahli, I., \& Rejeb, J. Ben. (2015). The Environmental Kuznets Curve and Corruption in the Mena Region. Procedia - Social and Behavioral Sciences, 195, 1648-1657. https://doi.org/10.1016/j.sbspro.2015.06.231

Sehar, M., \& Khan, A. (2013). Pakistan Institute of Development Economics, Islamabad Impact of Fossil Fuel Energy Consumption on CO 2 Emissions: Evidence from Pakistan (1980-2010). The Pakistan Development Review, 53(4), 327-346. https://doi.org/10.30541/v53i4Ilpp.327-346 
Shahbaz, M., Dube, S., Ozturk, I., \& Jalil, A. (2015). Testing the Environmental Kuznets Curve Hypothesis in Portugal, 5(2), 475-481.

Stern, D. I. (2003). The Environmental Kuznets Curve. Department of Economics, Rensselaer Polytechnic Institute. https://doi.org/10.1080/1350485042000207216

Stern, D. I. (2004). The Rise and Fall of the Environmental Kuznets Curve. World Development, 32(8), 1419-1439. https://doi.org/10.1016/j.worlddev.2004.03.004
Sugiawan, Y., \& Managi, S. (2016). The environmental Kuznets curve in Indonesia: Exploring the potential of renewable energy. MPRA Paper No. 80839. https://doi.org/10.1016/j.enpol.2016.08.029

Williamson, C. (2017). Emission, Education, and Politics: An Empirical Study of the Carbon Dioxide and Methane Environmental Kuznets Curve Emission, Education, and Politics : An Empirical Study of the Carbon. The Park Place Economist, 25(1).

Received on 18-07-2019

Published on 24-09-2019

DOI: https://doi.org/10.6000/1929-7092.2019.08.57

(C) 2019 Rodhiah Umaroh; Licensee Lifescience Global.

This is an open access article licensed under the terms of the Creative Commons Attribution Non-Commercial License (http://creativecommons.org/licenses/by-nc/3.0/) which permits unrestricted, non-commercial use, distribution and reproduction in any medium, provided the work is properly cited. 